\title{
Differential effects of pesticides on soil microflora in cultivated soil of Indian rice field agro-ecosystems
}

\author{
K alyanee Shar ma B hagabati ${ }^{* 1}$ and $\mathrm{H}_{\text {emen Sarma }}{ }^{2}$ \\ ${ }^{1}$ Department of Botany, Bajali College, Pathsala, 781325 (Assam), INDIA \\ ${ }^{2}$ Institute of Advanced Study in Science and Technology (IASST), Guwahati - 781 035, INDIA \\ *Corresponding author. E-mail: kalyaneebhagabati@gmail.com
}

\begin{abstract}
The present study was carried out to evaluate the effect of indiscriminant use of common pesticides especially insecticide on the population of soil micro flora in cultivated soil of Indian rice field agro-ecosystems. Endosulfan and Dichlorvos @ 1ml/l (normal dose) did not show any adverse effect on soil micro flora; but a high dose $2 \mathrm{ml} / /$ showed a negative effect. On the other hand Carbofuran @ $9 \mathrm{~kg} / \mathrm{acre}$ (normal dose) and 12kg/ acre (high dose) showed an adverse effect on the growth of actinomycetes, bacteria and fungi. The important findings of the present study is that the effect on microbes by applying insecticides reflects the ecological imbalance of microbes in cultivated soil and hamper the microbial equilibrium to some extent. The study focused that the uses of the pesticides as a plant protection agent occasionally hamper the growth of soil micro flora in cultivated rice field.
\end{abstract}

Keywords: Actinomycetes, Bacteria, Fungi, Pesticides, Rice field

\section{INTRODUCTION}

Soil is the natural habitat of microorganisms particularly actinomycetes, bacteria and fungi. These microorganisms play an essential role in maintaining the ecological balance of the soil. Their contribution to the soil and also plants and indirectly to man and animals are innumerable. Microorganisms have many beneficial uses. They can serve as feed for aquaculture (De Pauw and Persoone, 1992), as food for humans and animals (Becker,1992), in bioremediations of heavy metals contaminated site (Wilde and Benemann, 1993; Oswald, 1992.), and in agriculture productions as bio-fertilizer (Metting, 1992).

Increasing micro-algal populations in cultivated soil is being tested for its potential to increase yields of agriculturally important crop plants (Bashan and Holguin, 1997; Holguin and Bashan, 1996). However, in present day insecticides are used extensively to control insect and other pest which threat to population dynamics of soil microorganisms. The toxicity and persistent of these agrochemicals in soil, may raise serious problem to the microbial equilibrium.

Rice is the most important food crop of the developing world and feeds more than two billion people worldwide as a staple food (Datta, 2004). Besides, nowadays it is necessary to apply great amounts of pesticides to control pest whose growth is facilitated by present-day cultivation practices. Therefore, increased in utilization of pesticides is an important factor for obtaining high crop productivities and also protections from pest (Singh and Datta, 2006). However, the subsequent dispersions of those agrochemical compounds and/or of their degradation products have negative effects to the environment (Castro et al., 2005; Park et al., 2005).

The effects of soil micro flora following use of pesticides have been a subject of present interest through difference in doses and methods of assessing their effect, make comparisons hard. Studies on the effects of Bentazon and Molinate on Anabaena cylindrica of Portuguese rice field agro-ecosystems have provide extensive research foundations (Galhano et al., 2009). Insect pest make a grave problem in the field of agriculture but indiscriminate use of pesticide in cultivated field, creates deleterious effect to the population of soil micro flora. Researches had established that pesticide residue increased in the environmental media due to the indiscriminate use of these chemicals for the control of pest and vector (Deo et al., 1994).

The present study addresses this issue focusing the effect of pesticides on the population of soil micro flora in cultivated rice field soil of indan rice field agro ecosystem.

\section{MATERIALS AND METHODS}

The soil samples were collected from rice ruhizopheric zone and the numbers of colony forming unit (CFU) were isolated in cultural medium. In control soil, at initial stage the CFU for bacteria, actinomycetes and fiungi were 23.2, 9.5 and 152.2 respectively. The CFU of bacteria and actinomycetes were expressed in million and fungi was expressed in thousand per gram of soil. 
Three Pesticides viz Endusulfan 35\% EC, Dichlorvos 76\%, and Carbofuran (3\% G, Encapsulated) were used for the present experiment. Carbofuran $9 \mathrm{~kg} /$ acre (normal dose) and $12 \mathrm{~kg} / \mathrm{acre}$ (high dose) were applied; Endosulfan and Dichlorvos $1 \mathrm{ml} / \mathrm{l}$ (normal dose) and $2 \mathrm{ml} / \mathrm{l}$ water (high dose) were applied with the help of sprayer.

Soil samples were collected at 6 to $12 \mathrm{~cm}$ depth from the experimental field soil after application of the pesticides at the interval of $5,10,15,20,25,30$, and 35 days. The soil was analyzed for physicochemical properties with the help of standards analytical procedure and revealed that soil was sandy loam, $\mathrm{pH}$ was 6.39 , soluble salt was 0.235 $\mathrm{gkg}^{-1}$, total nitrogen was $1.43 \mathrm{gkg}^{-1}$, water holding capacity was $35.5 \%$ and soil moisture content was $18.5 \%$. Estimation of fungi, actinomycetes and bacteria were made using the dilution plate technique (Warcup, 1951).

\section{RESULTS AND DISCUSSION}

The application of Endosulfan $1 \mathrm{ml} / 1$ and $2 \mathrm{ml} / 1$ surrounding the transplanted rice seedling, showed that the two applied dose of Endosulfan had no effect on the population of fungi, actinomycetes and bacteria during the study period. On the contrary, a high dose of Carbofuran @12 kg/acre showed an adverse effect on fungal population. From the results it is evident that Dichlorvos@1 ml/l had no adverse effect on soil microbial population. On the other hand application of Dichlorvos@2 ml/l showed an adverse effect upon the growth of fungi, actniomycetes and bacteria.

In the present investigation it was recorded that 10 days after the application of Dichlorvos @ $2 \mathrm{ml} / 1$, the quantitative nature of fungi were found to decrease up to $145.0 \mathrm{CFU}$. However, after 30 days the number of fungal colony were found to reappear $(150.0 \mathrm{CFU})$ but not reach their original position $(152.2 \mathrm{CFU})$. The results also showed that the numbers of bacteria were found to be reduced up to 18.2 CFU at high dose of Dichlorvos.

The application of high dose of Carbofuran $12 \mathrm{~kg} / \mathrm{acre}$ showed an adverse effect and we recorded quantitative changes of actinomycetes and fungal populations in rice field soil. The changes were more distinct after 10 to 15 days of application. The fungal CFU were recorded as 148.5 after 10 days of application and after 15 days it again reduced up to 142.0. in the same way the actinomycetes also decreased and after 10 days, the CFU reached up to 9.2. The actinomycetes populations again reduced to $8 \mathrm{CFU}$ after 15 days of application and this has established that high dose of Carbofuran has toxic to microbes. However, the actinomycetes were found to maintain their original population after 30 days of application. The coccoid and rod shaped bacteria were again found to dominate after 30 days of the application of Carbofuran $12 \mathrm{~kg} /$ acre.

Actinomycetes are gram positive bacteria, which form branching hypha at some stage of their development and play a significant role in decomposition of complex organic material and recycling of material in nature (Jadhav and Deshmukh, 2006) and any disturbance of their growth in cultivated field soil my be detrimental for crop production.

Pesticides have been beneficial in increasing profits to farmers and also in total national production (Gough, 1977) but in the present time concerned have been raised about the health hazard of man by the application of pesticides. As pesticides are toxic to many insect and arthropods, it may also indirect toxic effect to microorganisms.

The application of Endosulfan in soil is not toxic to micro flora. On the other hand Carbofuran and Dichlorvos have some inhibitory effects on soil micro flora temporarily. From the results it is concluded that there is some effect on the population of micro flora in the soil treated with some pesticide as compared to the control soil and sometime constitute a threat to the microbial equilibrium in the soil.

\section{ACKNOWLEDGEMENTS}

This communications is an output of a Ph.D. research program at Gauhati University, Guwahati, India and the authors are grateful to the authorities of Gauhati University, for providing necessary institutional facilities in the Department of Botany.

\section{REFERENCES}

Bashan, Y. and Holguin, G. (1997). Azospirillum-plant relationships: environmental and physiological advances (1990-1996). Canadian J ournal of M icrobioogy, 43:103121.

Becker, E. W. (1992). Micro-algae for human and animal consumption. Pp. 222-256. In M icro-algal biotechnology (eds Borowitzka, M. A. and Borowitzka L. J.) Cambridge University Press, Cambridge, United Kingdom.

Castro, M., Silva-Ferreira, A. C., Manaia, C. M. and Nunes, O. C. (2005). A case study of molinate application in a Portuguese rice field: herbicide dissipation and proposal of a clean-up methodology. Chemosphere, 59:1059-1065. doi:10.1016/j.chemosphere. 2004.11.041.

Datta, S. K. (2004). Rice biotechnology: a need for developing countries. AgBioF orum, 7: 31-35.

De Pauw, N., and Persoone, G. (1992). Micro-algae for aquaculture. In M icro-algal biotechnology (eds Borowitzka, M. A. and Borowitzka L. J.) Cambridge University Press, Cambridge, United Kingdom.pp. 197-221.

Deo, P. G., Karanth, N. G. and Karanth, N. G. K. (1994) Biodegradation of $\mathrm{HCH}$ isomers in soil and food environment. CRC Critical Reviews in Microbiology, 20: 57-78

Galhano, V., Peixoto, F., Gomes-Laranjo, J. and FernándezValiente, E. (2009). Differential effects of bentazon and molinate on Anabaena cylindrica, an Autochthonous Cyanobacterium of Portuguese rice field agro-ecosystems. Water Air and Soil Pollution,197: 211-222. DOI 10.1007/ 
s11270-008-9804-y

Gough, H. C. (1977). Pesticides on crops -some benefits and problem. In Ecological effect of pesticides (eds Perring, F. H. and Mellanby, K. Linnaean Society of London, Academic Press.pp. 37-42

Holguin, G., and Bashan, Y. (1996). Nitrogen-fixation by Azospirillum brasilense $\mathrm{Cd}$ is promoted when co-cultured with a mangrove rhizosphere bacterium (Staphylococcus sp.). Soil Biology and Biochemestry, 28:1651-1660.

Jadhav, A. R. and Deshmukh, A. M. (2006). Biodiversity of Actionmycetes in Rankala and Kalamba Lakes of Kolhapur, Maharashtra. Nature Environment and Pollution Technology, 5:143-147

Metting, B. (1992). Micro-algae in agriculture. In M icro-algal biotechnology (eds Borowitzka, M. A. and Borowitzka L. J.) Cambridge University Press, Cambridge, United Kingdom. pp. 288-304.

Oswald, W. J. (1992). Micro-algae and waste-water treatment.
In M icro-algal biotechnology (eds Borowitzka, M. A. and Borowitzka L. J.) Cambridge University Press, Cambridge, United Kingdom. pp. 305-328

Park, B. J., Kyung, K. S., Choi, J. H., Im, G. J., Kim, I. S. and Shim, J. H. (2005). Environmental fate of the herbicide molinate in a rice-paddy-soil lysimeter. Bulletin of Environmental Contamination and Toxicology, 75: 937-944. doi:10.1007/s00128-005-0840-7.

Singh, S. and Datta, P. (2006). Screening and selection of most potent diazotrophic cyanobacterial isolate exhibiting natural tolerance to rice field herbicides for exploration as biofertilizer. J ournal of Basic M icrobiology, 46: 219-225. doi:10.1002/jobm.200510074.

Wilde, E. W. and Benemann, J. R. (1993). Bioremoval of heavy metals by the use of microalgae. Biotechnology Advances, 11:781-812.

Warcup, J.H. (1951). The ecology of soil fungi. Trans. Brit. Mycol. Soc., 34: 376-399. 